\title{
THE FEMINIST HUNGARIAN FOLKTALE AS POSTMODERN COMBINATORICS - THE ANALYSIS OF CSENGE VIRÁG ZALKA'S STORY-BOOK TITLED RIBIZLI A VILÁG VÉGÉN [CURRANT AT THE END OF THE WORLD]
}

\section{${ }^{\mathrm{a}}$ L. PATRIK, BAKA}

J. Selye University, Bratislavská cesta 3322, 94501 Komárno, Slovakia

email: ${ }^{a}$ bakap@ujs.sk

Abstract: In this paper we analyze the first story-book of the internationally renowned contemporary Hungarian storyteller, Csenge Virág Zalka. In the first section we investigate the differences between folktale and literary tale, storyteller and story writer, further-/retold heritage and own creation as well as how the boundaries between them destabilize if we note down the folktale originally living in the oral traditional form. Furthermore, we will be discussing the female horizon prevalent in the Zalkaian tale-variants as well as the all-time topicality of the stories by putting the contemporary social and psychological analogies and taboo-breaking procedures of the tales in the foreground. In the focus of our investigation the Ribizli a világ végén [Currant at the End of the World] stands as a literary creation, which although we (also) analyze with an approach coming from the relevant literature of folktales and remade fairy tales, we do this all the way through the analysis in light of the postmodern text-organizing strategies.

Keywords: Hungarian folktale, feminist features, postmodern text-organizing strategies, taboo-breaking solutions, topical problem management

\section{Introduction}

From many perspectives folktales are wormholes: they connect distant spheres in the blink of an eye. They cross the borders of the rational and irrational worlds as well as those running in between cultures. They are about the past, they bring us back to the era of myths, and at the same time they make us face with numerous challenges of the present - for only the world changes, men always stay the same. Similarly to how the plot of certain tale types is constant, the way they are formulated results in countless variants. This happens with every re-telling and rewriting. Exchanging some words or elements, the gesture of name-giving, the peculiar combinatorics of structuring the stories next to each other can create something entirely different, something refreshingly up-to-date.

In many aspects Csenge Virág Zalka's work also stands on a borderline. She is an international storyteller who writes (Trinity College), learned the craft of storytelling on American universities (East Tennessee State University, Bowling Green State University) and showed its heritage for example in the storytelling aspect of role-playing games in her monograph titled Forum-Based Role Playing Games as Digital Storytelling (Studies in Gaming) (Zalka 2019a). Her professional volumes intended for the wide audience, such as the Mesemondók márpedig vannak. A nemzetközi mesemondás világa [Storytellers Surely Exist. The World of International Storytelling] (Zalka 2016) - which plays a central role in the Hungarian reception of the topic -, and also the Hösök és pimaszok. Mit és hogyan meséljünk kamaszoknak? [Heroes and Cocky Ones. What and How to Tell Stories to Adolescents] (Zalka 2019b) deal with the past, present and challenges of storytelling. Therefore Zalka is not "only" a contemporary bard but the researcher and interpreter of storytelling as well. She is a traditionalist but at the same time she also proves, with the same level of professionality, the survival of traditions within the realm of contemporary popular culture. Furthermore, the international nature of her activity is also important: she retold Hungarian folktales - in a world language - at numerous places around the world. This aspiration of hers is proven by her volume titled Dancing on Blades. Rare and Exquisite Folktales from the Carpathian Mountains (Zalka 2018), in which she published Anna Pályuk's Transcarpathian tales in English. Through her works Zalka undoubtedly started a productive conversation about the practical and academic discourse on storytelling between the English and Hungarian dimensions.

The storyteller phrased the following ars poetica in the epilogue of her first Hungarian storybook, which is the subject of this analysis, Ribizli a világ végén. Régi magyar népmesék mai gyerekeknek [Currant at the End of the World. Old Hungarian Folktales for the Children of Today]: "I do not consider myself the writer nor the author of the stories in the book. I consider myself a storyteller, who does the same thing that storytellers have been doing since the beginnings of time: found a story, fell in love with it, began to tell it, and colored, polished and cherished it until every detail of it was shining” (Zalka 2019c, 229-230). In her writing she raises the same questions asked by many professional writers in connection to the works of Perrault, the two Grimms, László Arany, Gyula Illyés and Elek Benedek. Where is the boundary between folktales and literary tales, storyteller and story writer, further-/retold heritage and own creation as well as how the boundaries between them destabilize if we note down the folktale originally living in the oral traditional form? In general, this paper is dealing with these questions. Furthermore, it discusses the female horizon prevalent in the Zalkaian tale-variants as well as the all-time topicality of the stories by putting the contemporary social and psychological analogies and taboo-breaking procedures of the tales in the foreground. In the focus of our investigation the Ribizli a világ végén [Currant at the End of the World] stands as a literary creation, which although we (also) analyze with an approach coming from the relevant literature of folktales and remade fairy tales, we do this all the way through the analysis in light of the postmodern text-organizing strategies.

\section{2 ([Postmodern] Remade) Folktale}

The dilemma of the primacy of the oral or written form of tales has the same age as the research of tales and using a less scientific analogy, it is similar to the case of the chicken and the egg. It is clear that people started to speak - and tell tales orally, as opposed to in a written form, but we have ideas about what they were talking about and how they did it only since the time they started to write it down. "Therefore, the question rather is that how these written records influence speech, whether they influence it at all (obviously yes), in what degree the texts recorded in writing reflect real speech (obviously partially at most), and to what extent these recordings carry in them the unique peculiarities, the stylistic alignments etc. of the person who recorded them." (Liszka 2015, 99). The question of primacy has also been asked from the point of view of aesthetic quality. In this regard the heated argument between Albert Wesselski and Walter Anderson is one of the most memorable ones. According to the former, only the written down, stylistically treated tale counts as artistic creation, however, the latter, due to the oral and folklore basis of storytelling, considers the orally transmitted tale to have artistic value as well (Liszka $2015,100)$. Although it is not the consequence of this debate, it is a fact of scientific history that "during textualization, which is based on the notion of a confined and closed text, the complexity of storytelling usually got/gets lost, and it has only become the subject of scientific reflection mostly since the 1960 s by the significance of performance and context gaining more attention (Gulyás 2010, 51) in the Hungarian setting. Recently Ágnes Nagy Gabriella’s paper titled Hagyományos (nép)mesemondás [Traditional (Folk)Tale Telling] (Nagy 2017) profoundly discussed the performative nature and techniques of telling folktales, the types of storyteller narrators and about the resituating of telling folktales among various media. The foundation of the former is "the media anthropology established by Pfeiffer, which provides a framework to emphasize the phenomenon of storytelling from folklore events in a way so that it still remains part of the folk tradition and it becomes visible and interpretable among the cultural phenomena of today" (Nagy 2017, 189).

The performative acts of telling a tale have a big role in everyday pedagogical practice as well, since preschools and primary schools are highly important stages for the living on of folktales. In case of the storytelling of children they promote 
empathy and in case of the storytelling of teachers, besides the abovementioned, they mix with the features of pedagogical communication (Horváthová - Szőköl 2016, 31-40). In such cases the repetitions' function is not only to give emphasis or comply with numerology, but they also contribute to the acquiring of knowledge (Horváthová 2017). In storytelling addressed to children or performed by them a distinguished role is played by surprise aesthetics whose elements (updating, the use of unexpected similes, delaying formulas, character monologues) can be used to make the tale always contemporary and livable and to align it to the momentary needs of the community of children (Andrásfalvy et. al. 2001, 33-36). A deeper experience of the tales is enabled if it is immediately followed by playful activity. The innovative methods and practices of interactive pedagogy, the student-centered and problem-based learning (Tóth 2019, 83-100), the various playful, team-building, communicative, personality- and creativity-improving, drama and project-pedagogical tasks (Kerekes 2014; N. Tóth - Petres Csizmadia 2015, 297-322; Puskás 2019) - which can even span over certain arts (Csehi 1998, 76-79; Csehi 2020, 46-48) and media (Zolczer 2019, 233-234; 236-238) - play a crucial role in developing the competencies of children.

Instead of further discussing the work of storytellers and the pedagogical potential of storytelling, let us steer back to the activities of tale collectors. The most popular figures of the field, Perrault, the Grimms or Elek Benedek in numerous of their publications referred to themselves as the loyal recorders of texts originating on the lips of the folk. "So there is no extra coming from our own minds which we added to the tales - we did not beautify any relationship or feature in them [...]; the fact that the idiosyncrasy and the phrasing of things comes from us is selfevident, but we tried to preserve every peculiarity we could notice" (Grimm 2009, 13). Nevertheless, in their tale collections we can find many remaking and stylistic strategies specifically typical of them.

On a five-step gradual scale Ildikó Boldizsár showed to what extent and with the omission/replacement of which features can the literary tale - originally born from a folk tale inspiration get further away from the folktale. Boldizsár worked with the most extensive genre corpus: fairy tales. According to her evaluation, on the first step - on the first pole - we have the oral tradition fairy tales, which is the base form, the putting down of live speech word by word. On the fifth step - on the other pole there is the assimilated and specialized fairy tale with its own plot and motive system. The second step, the remade fairy tales, is the important one for us which includes the tales collected and at the same time remade by tale collectors who left their own fingerprints on them. These have their own peculiar style and their creators allow themselves to eliminate/replace some motives or elements which is mostly influenced by the consideration of the target audience, i.e. children (Boldizsár 1997, 15-17; 188-200). These peculiarities include: the classicist ornaments of Charles Perrault, the components of French etiquette and society integrated by him, the rhyming morals he wedged into the tales; in case of the Grimms it is the unification of the dialectal elements, the weeding out of obscene expressions, the totalization of fantastic elements and the iron hard rigor; and in case of Benedek it was morality, the educational aims, the glorification of the peasant-like conduct, the amplified prosaic rhythm, the varied beginning and closing formulas and the flavored expressions (Borbély 1999; Boldizsár 2004, 71-77, Petres Csizmadia 129; 134; 144-145). Furthermore, the collectors mentioned in the above order also adapted each other's tales and what is more, refolklorization the getting back to the oral tradition - is also a common feature of theirs. "What is generally true for a folktale, artificial tale, Grimm tale, for written and oral forms is that certain text variants were almost untraceably wandering around in the past centuries from a written form to an oral form and vice versa, from a folktale to an artificial one and back, perhaps with a short Grimm tale detour" (Liszka 2015, 102).
The American folklorist Ruth B. Bottigheimer defines two forms of this wandering. The oral form is essentially typical for the micro-spreading and it has a limited radius of impact both in time (a few generations) and space (small distances). She connects the publishing environment to macro-spreading which allows great ranges for propagation including the crossing of language boundaries (Bottigheimer 2011). Besides the (remade) tale collections of certain collectors and published by publishers and also the (often fragmented) materials of archives and ethnographic collections, we can associate the various sound and audiovisual recordings which preserve the storytelling evenings as performance shows with the latter, i.e. with macro-spreading. Bards operating nowadays (from a medial perspective, too) can draw from a much more extensive corpus, on the other hand, the indication of the sources and origins of the tale, the drawing of the quasi genealogy of the new generation tale-variant is expressed towards them almost as a professional expectation. In fact, this is the point at which we run into the recognition of the (also originally) postmodern organizing strategy of telling and writing folktales as well as into the recurring dilemma of the question of authorship.

In numerous of his papers Zoltán Németh has dealt with the phenomena of the postmodern, however, from the criteria offered by him for approaching certain works (Németh 2014) many seem to be applicable in case of the (ageless) folktales as well, since the attempt made on grasping the transcendent can be caught in the act, for example in the unidimensional worldview (Lovász 2007, 12-21), and also in the formal tradition in the fractally regenerating elements of identity aesthetics (Andrásfalvy et al. 2001, 22-32). The hiding of oneself can be discussed in connection to the characters' masks and metamorphoses, but also with respect to the collectors/authors as well, who contribute to the tale as sort of co-authors, but since they do this within limits, it is as if their identities would merge with those of the storytellers working before them who also had an impact on the story itself. Another, perhaps the most determinant merging point is also related to this: the totalization of intertextuality, as stylistic modification and the motive-like subtraction/addition/substitution is applied to an inherited material which at times is unmarked, and sometimes is marked. A good example for the latter is the indication of sources, which when done with comments - e.g. in case of Zalka -, is documenting the process of the structuration of the text. It is a wonderful gesture from Zalka that in the inherited material she names the yet unnamed female protagonist Anica, for she retold the tale variant of Anna Pályuk (Anica). The gesture is not simply paying respect or acknowledgment, but also the integration of the creator into the tale in which at this point there are not only various storytellers amalgamated, but there is a fusion of storytellers and protagonists as well, causing a multiple infringement of the levels of reality and fiction. There are postmodern patterns looking back on us in this solution and also in that the beginning and closing formulas can always be read as self-reflections.

Besides these features, folktales are - exactly because of their nature of being free of reference - independent of society or age and still remain up-to-date/updatable. The subordinated voice and the traumas suggested between the lines or with a word-hint dropped here and there succeed by no means only due to the remaking of the tales and the extras added to them. This is where the expertise of the collectors becomes important, since the seemingly infinite folktale corpus already contains these, it "merely" needs some professional combinatorics to put them in the spotlight. In certain cases this can happen within certain tales, but it can be even more emphatic while editing a volume, such as in the case of Ribizli. Csenge Virág Zalka did not replace princes with warrior princesses so that instead of a passive princess they would need to rescue a prince with the same attribute. She only retold tales which already are in this way, or in which the female and male characters are on the same level.

In light of all this - as in the postmodern in general - the dilemmas suggested previously do not get (re)solved. What is more, rather the boundary between folktale/artificial tale, 
storyteller/story writer, retold heritage/own creation gets questioned or blurry. A pure folktale does not exist, only a series of remade transcripts do, which, however, even in written form preserve their existence in variations, that is, in a certain way they safeguard the ancient form of folktales. The (live speech, performative) activity of storytellers and the (textual) one of story writers constitute one database and arm-in-arm with the phenomena of the era they offer a source of inspiration for the storytellers of the present. If these storytellers continue telling the heritage enriched with their own creativity then they extend it with themselves, they recreate it and merge with it along the strategies of postmodern combinatorics. Also for this reason we can completely agree with Zalka who says that "to preserve the tale in a fragmented form due to a respect for tradition, to keep it in a sort of frozen state, even if the audience of today does not understand a thing from it, [...] pays less respect to the genius storytellers of the past than if we, to our best knowledge, create a meaningful whole out of the inherited fragments" (Zalka 2019c, 229).

\section{Feminist folktales?}

Brian McHale's Postmodernist Fiction volume is widely considered to be one of the foundational works of the academic literature dealing with the poetics of postmodern literature. McHale emphasizes the aspirations of these works according to which they wish to give space to the voice of previously marginalized groups as well as to their historical experience, and this is something that the history functioning as the central great narrative does not count with. Among others such aspirations are the female horizons or the perspective of any nationality, racial, sexual etc. minorities. The works of the apocryphal history evolving this way often put the particular eras and events under an entirely different light (McHale 1987, 90). This aim resonates with Zoltán Németh's anthropological strategy which he describes as one of the manifestations (out of the three) of postmodern literature. It is typical for it that "it is sharply against authority, often acts openly political, it raises word against patriarchal, assimilative, homogenizative and globalizing tendencies with the purpose of preserving multicoloredness and the differing traditions" (Németh 2012, 35).

Naturally, the authors of contemporary literary works can move much more freely, if not within limitless frames, with the purpose of validating the marginalized viewpoint, which is something that cannot be said, or at least not in this form, about the storytellers working with folktales. The folktales including people have women for the most part in the same ratio as they have men. This is self-evident since without them marriage - the most wide-spread expression of eucatastrophe - would not be possible to come to fruition. The princess is one of Propp's seven permanent roles in fairy tales (Andrásfalvy et al. 2001, 24), which predestines the woman as the partner or reward of another character: the hero. This pattern takes effect in a significant portion of the folktale corpus, although not in all of them and what is even more important, by no means only as subordinated.

Csenge Virág Zalka asks the question: "If we want to nurse and preserve our own traditions, do we really have to give up the hope that our children could meet with diverse female idols in between the "once upon a time" and the »lived happily every after «?" (Zalka 2019c, 224). And the powerful "No" answer is represented by the bright princesses, kind witches and tricky female troublemakers in the tales of Ribizli. "These girls and women were not waiting for a savior: they slew the dragon themselves, they saved the kingdom, and they rightly became the ruler. The tale collection would have been complete without boys, princes and men who appeared next to these active women as equals" (Zalka 2019c, 225). Therefore Zalka did not write extreme feminist tales, but with her collection she proved that the Hungarian folktale realm is not interested in the totalization of distribution of the traditional gender roles, but preceding its era, it considers feminist values (Puskás 2013) as basic principles and it contains the realized emancipation from its very beginning. At least it is definitely the case in these thirty-nine tales - how exponential of a self-reflection of tale-number. "To my mind this is feminism; the heroes and heroines appear next to each other with equal value hierarchies” (Csapodi 2019) - says the storyteller, then elsewhere she adds: "Though when in the $19^{\text {th }}$ century they started to compile the tale collections for children, they were selecting them obliquely and in a biased way according to the zeitgeist of the time. It was not the tradition which was one-sided.” (Karafiáth 2020).

Among Zalka's stories we can find ones with numerous histories but pieces which are well known ones as well, and generally it can be said that she was collecting these tales from the entire Hungarian language region. Many of the tales can be classified among those exceptions of classical tale-treasures which provide enough space for identity-formation and for the psychological processes and doubts of relationship development, in contrary to those solutions where "the finding of the adult's role without any history or transition obviously is a fabulous element to the same extent as the topos of the love at the first sight providing the foundation to a lasting relationship" (Kappanyos 2019, 8). Many of Zalka's female and male tale heroes "saved each other, learned from each other, freely chose each other as partners and were able to admit their own mistakes as well" (Zalka 2019c, 225). Let us look at some examples.

In the tales of Ribizli there are specifically self-aware female characters who are typically "laborious and proactive in finding solutions to life situations” (Parti 2020). In A feneketlen kút [The Bottomless Well] none of the princesses is willing to kiss the suitor even against their father's command, who not incidentally is the only one unable to identify the cavalier. "My beloved father, if you need the ring so badly, kiss the devil yourself!" says the smallest one. And a few lines later we can read that: "The king has sent the word to the palace for Anica to come out. Anica sent the word back that if her father wishes to speak with her, he shall come inside" (Zalka 2019c, 8). The resistance here is not the expression of disobedience, but that of reason, which later even the king sees after realizing that the devil offered a fake ring for his daughters. The heroine in the A sárból gyúrt leány [The Girl Kneaded out of Mud] called Föld Gyengéje [The Weak One of the Earth] is one of the most active characters of the tale collection who - only due to her own talent -, from being a child of the poor gypsy people and being kneaded out of mud, became the savior of kingdoms, the conqueror of dragons and the darkness, and the equal partner of valiant soldiers. The latter could not be expressed better by anything other than what happened at the end: instead of the expected marriage they shook hands. With all this Föld Gyengéje refutes the prejudices connected to her origins, femininity, and name. The latter gets reinterpreted via the closing of the tale, since instead of indicating the "weakest", it can mean that the bearer of the name is the "gyengéje" [vulnerability] of everything on the Earth.

The love "on the first sight" is shaded in numerous places in the text of Zalka's tales. Although the Anica of A feneketlen kút, due to the lucky faith of the tale, can marry a soldier who had been promoted to a prince; the way "they smiled at each other with the slender man; it was clear that this is not the first time they have smiled at each other" (Zalka 2019c, 9). Thus the relationship - even if in secret - had enough time to evolve. In the A három vásárfia [The Three Fairings] via the king's wisdom the princess's permanent role becomes active when she can decide on her own which of the three suitors, who basically perform equally, she selects. One can argue with her reasoning, but not with her free will - this is the lesson here. In case of the A titokzatos beszédü lány [The Girl with the Mysterious Way of Speaking] the interest for each other is what becomes notable. Here it is not the suitor, the one who is seemingly the main character until two-thirds of the tale, but his brother - the escort - who becomes the protagonist by going back to the girl. "The girl opened the door with a smile on her face and invited the boy into the kitchen. I - I thought you won't even come back! / - I came back - admitted the boy. - I confess, the many questions we asked from you; I didn't understand any of your answers. Explain please” (Zalka 2019c, 31) - the boy asked. The girl's smile and words even retrospectively tell a lot about the previous 
scene's uncovered happenings and presumable looks shared among each other, however, the last two words of the boy are the expression of treating each other as equals. He does not consider her a fool for not talking clearly - like his brother did - but rather he asks for clarification. He is curious. It is important though that the protagonists of some of the tales do not find a mate. For example, despite the offer, the last member of the trio in Hapták, Kerdáj, Rékcung, does not wish to marry the princess who has played him so many times; instead he very consistently chooses Julcsi, her handmaid.

Romantic intimacy appears in between the lines and in forms of references in the stories. After a short dilemma, for example, it becomes obvious in the $A z$ aranyhajú kertészbojtár [The Goldilocks Gardener-Boy] at the point when the girl finally "without a word took the comb from his hands and she continued to comb the golden hair" (Zalka 2019c, 89). However, Ribizli is driven away and turned into a lizard by the convent school director because "she was displaying herself in the window [of the convent]" and "was seducing the princes" (Zalka 2019c, 70), which - even despite the intense protest of the girl - is counterpointed by a statement from the narrator from earlier: "she wasn't keen about a life in a cloister, she was always looking out of the window" (Zalka 2019c, 70). Ribizli [Currant] "was given this unique name because since her childhood she wasn't willing to eat anything else" (Zalka 2019c, 69), but later we find out that it could be red, white or black currant as well. According to color-symbolism the character is connected to sexuality, innocence and loss/the marching out of this world as well (Pál et al. 2001), which is also verified by the story. Although it is not revealed how close Ribizli got to the prince previously, it is clear that while being turned into a lizard she herself was helping him in fulfilling his tasks, and meanwhile the prince also restored her world. Therefore they had plenty of time to get to know each other and all this certainly happened with physical intimacy suspended.

Perhaps Zalka's most emphatic solutions for strengthening the female position is name giving, which is something that the female characters are in a significant disadvantage in the folktale treasury. "I felt that all the girls and women who remained unnamed also deserve a name[.] [...] Aside from one or two exceptions (where the girlness of the girl or the grannyness of the granny seemed more important than their first name) where there was no name, I borrowed one from another tale of the same tale collection or from another version of the same tale type [...]. In a few cases I named a character after the original storyteller in order to pay my respects to them" (Zalka 2019c, 229). We can rightly consider the collection which was realized among the lines of the female position as well as this form of name giving as the manifestation of McHale's apocryphal history and Zoltán Németh's anthropological postmodern strategy both within the framework provided by folktales. Thus the girls/women/old ladies do not remain an unnamed blend of mass in the shadows of Fehérlófia [The Son of White Horse], Király Kis Miklós [King Little Nicholas] and their company, but they become independent individuals who are equal partners of men as Ribizli, Zsófia [Sophie] or Anica.

\section{All-time timeliness - social and psychological analogies, de- tabooing}

Tales have played an honored role in all cultures and they continue to do so to this day. We can find them in the rites of the archaic societies who used them to celebrate the stations of human maturation. In the Jewish culture religious education was always linked to storytelling; this is why they were telling tales to the newlyweds on their traditional weddings. In case of the Christians the parables about Jesus teach us the morals, and for the Muslims tales are the tools for easing off after a whole day of fasting during the Ramadan (Boldizsár 2010, 24-25). Besides entertainment, the knowledge-shaping function of tales is also determinant. They promote immersion, they improve tolerance and the problem-solving skill, and according to the results of Ildikó Boldizsár and other professionals, they have a healing effect as well. The basis of the latter is the feature of tales that only their beginning and closing sections are harmonious, however the biggest, inner part of the tale is full of challenges and battles which the characters fight for winning back the equilibrium. In addition to the fact that the patient and usually the reader puts this fight in parallel with their own, the wonderful quality "makes it obvious that tales do not want to convey knowledge about the outside world but rather about the inner processes of the self' (Bettelheim 2011, 29). The sensitivity of tale therapy means that the symbols of the tale open for the recipient only to the extent at which they can currently tolerate them, and the steps of resolution and comprehension have emotionally energizing effects (Boldizsár $2010,54-56)$. In light of all this, one can state that tales "are about the fact that a person at any time during their life can be more than what in the current moment they experience, what is more, everything that functions incorrectly in the world can be changed" (Vas, 2014, 209). Due to overcoming of their difficulties, the tale heroes of Zalka also can get a role in this process.

In the tales of Ribizli we very often are faced with (all-time) topical elements of social criticism. The most classical is the story of the A láthatatlan munka [The Invisible Labor] which renders the primacy question of female and male labor pointless. And this question "whether you like it or not, is topical. Even today still many find it evident that the soap dish never gets empty at home...” (Csejtei 2020). The treasurer of Vidám Királyfi [Merry Prince] confronts us with embezzlement and corruption, whose position ultimately is filled in - as sort of a counterpoint by the fisherman father-in-law of the ruler, who due to their poverty did not even want to let her daughter into the court, despite them asking her to be the queen. At times this is enough for drawing full characters. Similarly to the two older princes of Ribizli a világ végén who, contrary to their brother, tried to solve all their tasks with money. The A három vásárfia confronts us with hostility and the sometimes meaningless declaration of public opinion, when all subjects know which prince should the king choose - it is just that they have nothing to do with it. "[T]opics which are at the minimum flabbergasting appear here. The escape from the toxic family, abusive husband or harassing father. Growing up in a broken family. The cursing of children and the difficulties of lifting the curse. The overcoming of the boy-father or tyrant-mother arbitrariness, free mate selection, the taming of the unrestrained powers" (Stenszky 2020), but also respecting the elderly comes up in many tales. The A szegény asszony és a sárkány [The Poor Woman and the Dragon] confronts us with the prejudices against the Romani people, the Igazmondó Lörinc vitéz [Truth-Telling Valiant Soldier Lőrinc] makes us face harassment, where although the guilty gets the punishment, the case is not closed with this. "And for you, my daughter, I do not simply allow to spit in the eye of anyone who wishes to hug you against your will, but I order you to slap them as well!" (Zalka 2019c, 160) - the ruler says with a roar. With this the tale not only reacts to the scandals of our recent past, but it also emphasizes: if we want to put and end to harassment, the first thing to do is that the victims have to break the silence.

In several stories some of the motives of ancient Hungarian culture come to life. In Incula not only the eponym princess is a táltos [priest, healer, sage], but the only cure for her father's illness is the turul bird [ancient Hungarian mythological bird]. Here the (ancestral) national symbol and the cure are in a metonymical connection, and the liberation of the turul can symbolize the aspirations of revealing the past. In this sense the latter is also a self-reflection, since, to a considerable extent, this process is only made possible by the results of ethnography or by the conveying and the keeping alive of inherited traditions for example with the telling of folktales. The fact that at the end of the tale Incula becomes a táltos princess resituates the place of women in old Hungarian culture. The A híres szittya király fiai [The Sons of the Famous Scythian King] guards the memory of the adventure era. One of its heroes, Aladár, is not only the eponym of the Botond monda [Botond legend], but also he can be put in parallel with the Biblical David through his fight with the giant. A princess of the same tale, Heléna, shows kinship with Helen of Troy from Iliad. The tripled golden apple throwing 
of the Az aranyhajú kertészbojtár evokes the case of Paris and the goddesses of antiquity, and the A sárból gyúrt leány as well as the A pirosmalac [The Red Piglet], due to getting - here slightly alternatively - blessed with a child quite late draws a parallel with the story of Abraham.

We can also highlight the family structures which differ from the traditional model (a more recent volume of the storyteller, Széltestvér és Napkelte [Wind-Sibling and Sunrise] [Zalka 2020a]). In the A feneketlen kút "[the] three princesses were born from three mothers" (Zalka 2019c, 5), but were growing up at their father's. There were differing reasons for why the first two wives left. One of them was a fairy and when the fairies left the human world she went with them "up to the starry sky" (Zalka 2019c, 6). This phrasing suggests that death might have been the reason for the end of the marriage. The second wife, a women of science ultimately had to leave because of her science, since people in the court were accusing her with witchcraft. Here the reason was also not the spoiled king-queen relationship, although the gossip might have established a basis for this. Only the third girl has a simple mother, however, they do not quarrel with each other, and the king does not make exceptions with any of them either. Furthermore, with the first wife it was a multicultural one, while with the second one it was a marriage of two with different "educations". The female hero of the Tengöri Hereberi Atyámuram, on the one hand becomes memorable because of her loyalty - since she makes three seducers laughable while waiting for them "naked" in the bed -, and on the other because she tolerates another wife of her husband, besides herself. "They sat down next to each other, they talked for a while, then they turned to Principci: they decided that they won't mind if both of them remain a wife" (Zalka 2019c, 195). With this turn the tale does not only face the tradition of the purely monogamist marriage, but it also opens up the question of sexual orientation.

The potential traces of homo-, bi- and transsexuality appear on multiple places, be it playful situations or the emphasized search for ones identity. It is typical for these sections that they have a humorous - but definitely not derisive - style, which might make the reception easier (or just differently understandable) for those who are averse to these ideas. "The king looked upon the devil. The devil also looked on the king. The king really wanted to get back his ring... therefore he leaned over and gave the devil a smack on the lips" (Zalka 2019c, 8). The previous quote from the A feneketlen kút is only a game; the question of sexuality is emphasized most markedly in the tale titled Vitéz Rózsa [Valiant Soldier Rose], in which all three princesses try to slip into a male role. All three "went to see the barber, had a haircut, put on valiant soldier clothes, and took off for the world" (Zalka 2019c, 98), but only Rose gets through the copper, silver and golden forest too, which are sort of level markers for the steps of becoming a man. Rose proves to be a superb soldier insomuch as even Ilona Tündér [Helena Fairy] wishes to marry her. The text does not reveal whether Ilona knows about Rose's girlness, but that the latter "who really started to like Ilona Tündér" (Zalka 2019c, 102) also continues acting to this purpose makes the question of sexuality undoubtedly topical. From this point of view the fact that due to Saint Peter's curse - "If you were a boy, turn into a girl, if you were a girl, turn into a boy!" (Zalka 2019c, 104) - Rose's "body changes" (Zalka 2019c, 104) and allows a pass for heterosexual marriage is basically secondary, since Rose felt attracted toward Ilona Tündér even as a women. The latter opens the horizon of lesbianism, and the knighthood aspect and strongly masculine function of it introduces transsexuality. The Béla kisasszony [Lady Béla] seemingly also raises the previous questions, but in that one we "only" have a female hero who can alternate between male and female roles and identities and who does not relativize her girlness and sexual orientation even despite her name [Béla is a common Hungarian male first name]. "Gender identity is not necessarily equal with gender expression. If a girl wears jeans, a T-shirt and male shoes, it doesn't necessarily mean that she wants to be a boysimply that's what she likes, that's what's comfortable for her [...], because it fits better to her personality when she's currently in a lady of the castle status" (Zalka 2015a) - says Zalka herself as her own evaluation of the story, which in this form is the critique of the this or that way of thinking.

The storyteller does not weed out the cruel parts of the stories either, at most she renders them with a rhetoric solution. For example, when the green dragoon was "[f]rying and frizzling" (Zalka 2019c, 15) over the fire, when the witch in the Incula (although accidentally, but) slaughters all seven of her children or when in the A híres szittya király fiai the cut off hands of the twelve outlaws are poured out of a sack. The cruelest scenes are in A szépen zengö pelikánmadár [The Nicely Ringing Pelican], in which the kidnapped and then robbed princesses are thrown into the scythe-well by the fraud princes. "In this tale love doesn't defeat everything. The princess, after seeing the attractive prince for what he really is, doesn't try to save him or shift responsibility to the remaining two siblings" (Zalka 2015b). The tales in this way preserve the eye for an eye principle which is an important tool for restoring order in the classical tradition.

Certain linguistic solutions and notions of the stories fit into the updating strategy of surprise-aesthetics by which the tales are brought closer to the present era. For instance the green dragoon is beaten by an umbrella, or that they try to roast him in a frying pan and on a roasting dish. His wife happens to have a coffee glass while the king of Vitéz Rózsa likes to read newspapers. In the A tengerlépö cipö [Sea-Crossing Shoes] they send for firefighters to help the poor man get off from the church tower, and the princes of the A három vásárfia mark their path, out of the three available ones, with a pocketknife.

As closure we might mention the genre-related self-reflections which are the strongest in the tale titled Egy halottban hét eleven [Seven Living in one Dead]. In a certain sense the beginning and closing formulae always count as strong ones, but here we have the following overture: "Once upon a time - if there hadn't been a time, I wouldn't be telling you about it -, there were two lovers in a village" (Zalka 2019c, 76). Therefore, at this point, the love is already interpreted as a given, only its social fulfillment is blocked by existential and financial issues. The boy gets into the bad ways when he tries to solve his problem by stealing, but he gets collared and the punishment is hanging. Only his lover can save him if she can come up with a riddle which nobody can answer. "The more she was thinking, the more she became worried that none of them will be good enough. She learned riddles since she was a child from the elderly of the village, her parents and from the other children; they were shared by wordof-mouth so she wasn't sure whether any of them would be recognized by someone from the village" (Zalka 2019c, 76-77). Thus the riddle here functions as the key to survival, and due to the previously mentioned features, it is the analogy of the tales as well. As the self-validating insertion in the beginning formula of the story is a reference to the all-time validity of tales, the solution of the story, the creation of a new riddle (in other words tale, or maybe tale-variant) founded on real and contemporary basis is the key to the rescue and survival of the boy, storytelling and also to folk culture.

The volume is illustrated by the unique and ageless pictures of László Herbszt. The patterning solutions of the latter whose industrial elements, while evoking the parts of a machine which return the same way as the backgrounds and the surfacefilling patterns -, are the manifestations of the depths residing under the surface and the repetitions specific to folktales in a different medial context but at the same time being operationally analogous to them (Kocsis 2020). We can rightly consider the rich, vivid and saturated colors of the figures as updating markers, and "the pattern on the inner cover can also be found under the titles, reminding the reader for the revived folk motives fitting for the revived texts, and also showing that they can find the permanence referring to tradition and the innovative visual world in the geometric shapes and colors of the drawings" (Parti 2020). 


\section{Conclusion}

As it could be noticed on the continually integrated details, Csenge Virág Zalka uses a "clean but at the same time dynamic and live language. An enormous merit of hers is that she found a written, but also readable language for the tales narrated by her which can move both the feelings and the imagination of the reader" (Hansági 2020). Although she gives voice to the old heritage, she does it with a modern language, modern tools and according to modern criteria. A determining element of her poetics is humor and with it she makes the material lifelike, but at the same time she is far from using exaggerated simplifications, which makes the works for the wide and ageless readership remain exciting. Since then a second volume of the collection was completed in a similar spirit, but containing a selection from the tale treasury of the whole world and having the title of A kalóz királylány. Nemzetközi népmesék mai gyerekeknek [The Pirate Princess. International Folktales for Children of Today] (Zalka 2020b).

Zalka’s work and first tale collection, the Ribizli a világ végén with which she earned the prize of the Best Children's Book of the Year 2019 in Hungary (Hubby 2020) -, besides many other things, has shed light on the role of the already emphatic female horizon which she further strengthened by the possibilities of storytelling/story-rewriting in the Hungarian folktale corpus, and she also illuminated the fact that the all-time topicality of tales is not an empty phrase, but a continually proven fabled feature.

\section{Literature:}

1. Andrásfalvy B. - Balassa I. - Égetö M. - Gráfik I. - Gunda B. - Kotics J. - Paládi-Kovács A.- Petercsák T. (2001): Magyar néprajz V. A magyar népköltészet [Hungarian Ethnography], Educatio Társadalmi Szolgáltató Nonprofit $\mathrm{Kft}$. = https://regi.tankonyvtar.hu/hu/tartalom/tkt/magyar-neprajz-magy ar/ch26s05.html

2. Bettelheim, B. (2011): A mese büvölete és a bontakozó gyermeki lélek [The Charm of Tales and the Unfolding Soul of Children], Corvina, Budapest, 347 p. ISBN 978-963-13-6018-9

3. Boldizsár I. (1997): Varázslás és fogyókúra [Magic and Diet], Didakt, Debrecen, 219 p. ISBN 963-8569-65-4

4. Boldizsár I. (2004): Mesepoétika [Tale Poetics], Akadémiai, Budapest, 312 p. ISBN 963-05-8178-7

5. Boldizsár I. (2010): Meseterápia. Mesék a gyógyításban és a mindennapokban [Tale Therapy. Tales in Healthcare and on Ordinary Days], Magvetö, Budapest, 367 p. ISBN 978-963-142846-9

6. Borbély S. (1999): Klasszikus meseirodalom [Classical Tale Literature] = Komáromi G. (szerk.), Gyermekirodalom [Children's Literature], Helikon, Budapest, 84-98. p. ISBN 963208-610-4

7. Bottigheimer, R. B. (2011): A tündérmesék eredete, terjedése és a népi narrativa elmélete [The Origins and Spread of Fairy Tales and the Theory of Folk Narrative], ford. Vásáry Á., Etnoszkóp, 2011/1, 107-115. p. ISSN 2063-2177

8. Csapodi M. (2019): Mindenkinek szüksége van a mesemondás varázslatára - Zalka Csenge a Mandinernek [Everyone Needs the Charm of Storytelling - Csenge Zalka for the Mandiner] [Interjú - Interview], Mandiner = https://mandiner.hu/cikk/2 0190623_zalka_csenge_interju

9. Csehi Á. - Dombi E. (1998): Zeneirodalmi, zenehallgatási szemelvények a gyermekek és az ifjúság részére I. [Excerpts from Music Literature and Music Listening for Children and Young Adults I], Lilium Aurum, Dunaszerdahely, 99 p. ISBN 978-80806-202-40.

10. Csehi, A. (2020): The Transfer Effect of Musical Activities in Terms of Abilities and Personality Development - About the Results of a Music-Pedagogical Study, AD ALTA: Journal of Interdisciplinary Research, 2020/2, 46-50. p. ISSN 1804-7890 11. Csejtei O. (2020): Az Üveghegyen túl, feminizmuson innen Zalka Csenge Virág hösnökröl és bátor királylányokról [Once Upon a Time, In a Feminist Land], Népszava = https://neps zava.hu/3081215_az-uveghegyen-tul-feminizmuson-innen-zalka-csenge-virag-hosnokrol-es-bator-kiralylanyokrol
12. Grimm, J. \& W. (2009): Családi mesék [Family Tales], ford. Adamik L. - Márton L., Kalligram, Pozsony, 688 p. ISBN: 9788081012068

13. Gulyás J. (2010): „Mert ha irunk népdalt, mért ne népmesét?” A népmese az 1840-es évek magyar irodalmában ["Because If We Write a Folk Song, Why Not a Folktale?" Folktales in the Hungarian Literature of the 1840s], Akadémiai, Budapest, 352 p. ISBN: 9789630587518

14. Hansági Á. (2020): Hansági Ágnes laudációja [Laudation for Ágnes Hansági], Hubby = http://hubbyinfo.blogspot.com/202 0/06/hansagi-agnes-laudacioja-zalka-csenge.html

15. Horváthová K. - Szököl I. (2016): A pedagógiai kommunikáció [Pedagogical Communication], Selye János Egyetem Tanárképző Kara, Komárom, 138 p. ISBN 978-808122-175-0

16. Horváthová, K. (2017): Redundancy in the verbal communication of teachers in primary education, Journal of Language and Cultural Education, 2017/3, 93-107. p. ISSN 1339-4045

17. Hubby (2020): Év Gyerekkönyve Díjak - 2020, [Best Children's Book of the Year Prizes - 2020] Hubby = http://hubbyinfo.blogspot.com/2020/06/ev-gyerekkonyve-dijak2020.html

18. Kappanyos A. (2019): Az elveszett ártatlanság és a visszanyerhetö intimitás [The Lost Innocence and the Retrievable Intimacy], Prae, 2019/2, 6-12. p. ISSN 1585-5112

19. Karafiáth O. (2020): Zalka Csenge Virág: „Nehéz körbeírni, miben is különbözök a hagyományos népi mesemondóktól” ["It Is Hard to Describe How It Differs from Traditional Folk Storytellers"] [Interjú - Interview], MagyarNarancs = https://mag yarnarancs.hu/konyv/aki-megfurdik-megoregszik-132657

20. Kerekes V. (2014): Mesét Másként. Népmese és drámapedagógia az óvodai nevelésben [Tales in Another Way. Folktales and Drama Pedagogy in Preschool Education], Fordulópont, XVI. évf., 63. szám, 49-55. p. ISSN 1585-2474 21. Kocsis K. (2020): A pillanat, ahol átfordul a mese - interjú Herbszt László illusztrátorral [The Point Where the Tale Turns Interview With Illustrator László Herbszt], Kultúra.hu = https://kultura.hu/herbszt-laszlo-ribizli/

22. Liszka J. (2015): Népmese vagy mümese? Gondolatok egy Grimm-mese kapcsán [Folktale or Artificial Tale? Thoughts Regarding a Grimm Tale] = H. Nagy P. - Keserü J. (szerk.): A párbeszéd eleganciája. Köszöntö kötet Erdélyi Margit tiszteletére [The Elegance of Dialogue. Salutation Volume In Honor of Margit Erdélyi], Selye János Egyetem Tanárképző Kar, Komárom, 99-114. p. ISBN 978-80-8122-120-0.

23. Lovász A. (2007): Jelen idejü holnemvolt [Once Upon a Time in a Present Tense], Krónika Nova, Budapest, 184 p. ISBN 978-963-9423-79-4

24. McHale, B. (1987): Postmodernist Fiction, Routledge, London - New York, 278 p. ISBN 9780415045131

25. N. Tóth A. - Petres Csizmadia G. [összeáll.] (2015): Módszertani szöveggyüjtemény az irodalom oktatásához [Methodological Text Collection for Teaching Literature], Nyitrai Konstantin Filozófus Egyetem Közép-európai Tanulmányok Kara, Nyitra, 324 p. ISBN 978-80-558-0744-7

26. Nagy G. Á. (2017): Hagyományos (nép)mesemondás [Traditional (Folk)Tale Telling] = Hansági Á. - Hermann Z. Mészáros M. - Szekeres N. (szerk.): Mesebeszéd. A gyerek-és ifjúsági irodalom kézikönyve [Tale Speech. The Handbook of Children's and Young Adult Literature], FISZ, Budapest, 169222. p. ISBN 9-786155-729058

27. Németh Z. (2012): A posztmodern magyar irodalom hármas stratégiája [The Triple Strategy of Postmodern Hungarian Literature], Kalligram, Pozsony, 133 p. ISBN 978-80-8101-640-0 28. Németh Z. (2014): Költészet és nemiség... Hálózatelmélet és irodalomtörténet-írás [Poetry and Sexuality... Network Theory and Writing Literary History] = Csanda G. - H. Nagy P. (szerk.): Költészet és... [Poetry and...], Szlovákiai Magyar Írók Társasága, Pozsony, 87-102. p. ISBN 978-80-971166-6-8

29. Pál J. - Újvári E. - Borus J. - Ruttkay H. (2001): Szimbólumtár. Jelképek, motívumok, témák az egyetemes és a magyar kultúrából [Symbol Collection. Symbols, Motives, Themes from Universal Hungarian Culture], Balassi Kiadó, Budapest $=$ https://regi.tankonyvtar.hu/hu/tartalom/tkt/szimbolu mtar/ch03s03.html 
30. Parti J. (2020): Meséld újra! Ribizli a világ végén [Retell It! Currant at the End of the World], Mesecentrum = https://igyic. hu/konyvajanlok/meseld-ujra.html

31. Petres Csizmadia G. (2015): Fejezetek a gyermek- és ifjúsági irodalomból [Chapters from Children's and Young Adult Literature], Nyitrai Konstantin Filozófus Egyetem Középeurópai Tanulmányok Kara, Nyitra, 256 p. ISBN 978-80-5580903-8.

32. Puskás, A. (2013). What is a woman? Female Identity in the Mirror of Feminist Criticism = Bárczi Zs. - Petres Csizmadia G. (szerk.): Narrative construction of identity in female writing, Eötvös University Press, Budapest, 9-38. p. ISBN 978963312 1818

33. Puskás, A. (2019): Higher education challenges: Improving cooperation and creativity by using drama techniques in EFL teacher training = Callaos, N. - Chu, H.-W. - Horne, J. (eds.): IMCIC'19: The 10th International Multi-Conference on Complexity, Informatics and Cybernetics, International Institute of Informatics and Systematics, Orlando, 153-158. p. ISBN 9781-941763-97-1

34. Stenszky C. (2020): Feminizmus a magyar népmesékben [Feminism in Hungarian Folktales], Irodalmi Jelen = https://irodalmijelen.hu/2020-aug-17-1128/feminizmus-magyarnepmesekben

35. Tóth P. (2019): A problémaalapú tanulás [Problem-Based Learning], Selye János Egyetem Tanárképző Kara, Komárom, 112 p. ISBN 978-80-8122-337-2

36. Vas K. (2014): „,Mesés” lehetőségek a gyógyitásban és az oktatásban ["Fabled" Possibilities in Healthcare and Education] = Erdélyi M. (szerk.), Az irodalomoktatás új kihívásai [The New Challenges of Teaching Literature], Gondolat Kiadó, Budapest, 199-222. p. ISBN 9789636935399

37. Zalka Cs. V. (2015a): Feminista Magyar Népmesék 4. - Béla kisasszony [Feminist Hungarian Folktales 4 - Lady Béla], A Tarkabarka Hölgy Naplója = http://tarkabarka.blogspot.com/ 2015/12/feminista-magyar-nepmesek-4-bela.html

38. Zalka Cs. V. (2015b): Feminista Magyar Népmesék 2. - A szépen zengö pelikánmadár [Feminist Hungarian Folktales 2 The Nicely Ringing Pelican], A Tarkabarka Hölgy Naplója = http://tarkabarka.blogspot.com/2015/11/feminista-magyarnepmesek-2-szepen.html

39. Zalka Cs. V. (2020a): Széltestvér és Napkelte. Hagyományos mesék rendhagyó családokról [Wind-Sibling and Sunrise. Traditional Tales about Irregular Families] (Bertóthy Á. illusztrációival), Móra, Budapest, 160 p. ISBN 9789634865759 40. Zalka, Cs. V. (2016): Mesemondók márpedig vannak. A nemzetközi mesemondás világa [Storytellers Surely Exist. The World of International Storytelling], Pont, Budapest, 248 p. ISBN 9786155500176

41. Zalka, Cs. V. (2018): Dancing on Blades. Rare and Exquisite Folktales from the Carpathian Mountains, Parkhurst, Michigan, 224 p. ISBN 978-1624911033

42. Zalka, Cs. V. (2019a): Forum-Based Role Playing Games as Digital Storytelling (Studies in Gaming), McFarland, Jefferson North Carolina, 215 p. ISBN 978-1476672847

43. Zalka, Cs. V. (2019b): Hösök és pimaszok. Mit és hogyan meséljünk kamaszoknak? [Heroes and Cocky Ones. What and How to Tell Stories to Adolescents], Pont, Budapest, 142 p. ISBN 9786155500558

44. Zalka, Cs. V. (2019c): Ribizli a világ végén. Régi magyar népmesék mai gyerekeknek [Currant at the End of the World. Old Hungarian Folktales for the Children of Today] (Herbszt L. illusztrációival), Móra, Budapest, 238 p. ISBN 9789634862482 45. Zalka, Cs. V. (2020b): A kalóz királylány. Nemzetközi népmesék mai gyerekeknek [The Pirate Princess. International Folktales for Children of Today] (Herbszt L. illusztrációival), Móra, Budapest, 208 p. ISBN 9789634866497

46. Zolczer, P. (2019): Using Video Games as Sources for Storybased English Classes = Bukor J. - Simon Sz. (szerk.): 11. International Conference of J. Selye University. Section on Language - Culture - Intercultural Relationships, J. Selye University, Komárno, 231-241. p. ISBN 978-80-8122-331-0

Primary Paper Section: A

Secondary Paper Section: AJ, AM 